\title{
Response of sediment to ice-sheet loading in northwestern Germany: effective stresses and glacier-bed stability
}

\author{
Jan A. Piotrowski, Anna M. Kraus \\ Institute of Geology and Palaeontology, University of Kiel, D-24118 Kiel, Germany
}

\begin{abstract}
Laboratory tests on sediment over-ridden by the last ice sheet in northwestern Germany reveal very low ice-induced pre-consolidation and high palaeo-porewater pressures. Sediment consolidation at the base of the glacier was largely controlled by hydraulic properties of the substratum. Generally low permeabilities of the bed caused sustained high pore-water pressure in over-ridden sediments close to the flotation point. This implies a serious possibility of hydraulic lifting of the ice sheet. It is believed that the reduced basal coupling limited the transformation of glacier shear stress on to the bed sediments, which is indicated by a lack of sedimentological evidence for widespread pervasive bed deformation. Ice motion was probably focused at the glacier sole by some combination of sliding and ploughing. However, isolated spots with deformation occur, so that the subglacial system in the study area can be characterized as a stable/deforming mosaic.
\end{abstract}

\section{INTRODUCTION}

Reconstructing the behaviour of Pleistocene ice sheets requires accurate values for factors influencing the basal boundary condition, such as mechanisms of subglacial meltwater drainage and the behaviour of over-ridden unconsolidated sediment. Since no direct data on these parameters are available, one must rely on inferences from signatures left in subglacial sediments and ultimately use them for validation of large-scale palaeo-glaciological models of icesheet dynamics.

The objective of this paper is to demonstrate unexpectedly high palaeo-pore-water pressures within fine-grained sediments over-ridden by the last (Weichselian) ice sheet in northwestern Germany, as indicated by laboratory tests on undisturbed till and clay samples. Among possible causes for apparently sustained high water pressures, low hydraulic conductivities of the substratum will be considered. An attempt to reconcile high pore-water pressures with apparent lack of field evidence for pervasive ice-bed deformation is made. This leads to the conclusion there was a thin subglacial water film, which locally separated subglacial sediments from the shear stresses imposed on them by the glacier movement.

\section{SEDIMENT CONSOLIDATION}

A vertical downward stress, $\sigma_{z}$, applied to sediment causes consolidation of the grain skeleton. Sediment consists of largely incompressible minerals and pore space, filled with air or water (Fig. la). When sediment is over-ridden by a glacier, normal stress increases and initiates consolidation. At first, there is consolidation due to expulsion of air, followed by consolidation caused by squeezing of water out of the pores. The latter accounts for most consolidation and depends on the hydraulic and geometric properties of the material and on pore-water recharge. If the pore-water can

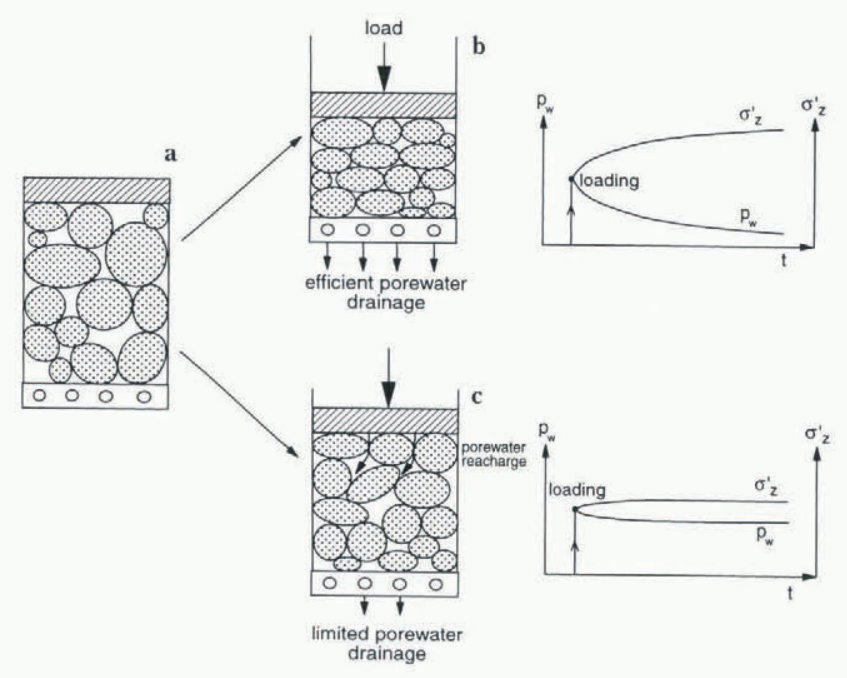

Fig. 1. Geostatic compaction of a clastic sediment (a) with pore-water drainage $(b)$ and with limited pore-water drainage and pore-water recharge $(c)$ (modified after Boulton and Dobbie, 1993). $p_{\mathrm{w}}$ is pore-water pressure, $\sigma_{z}^{\prime}$ is effective stress. (c) illustrates a subglacial system with low hydraulic permeability under a warm-based glacier. Note only slight changes in $p_{\mathrm{w}}$ and $\sigma_{z}^{\prime}$ after loading in (c).

drain freely from the sediment, consolidation is rapid and significant with rapid pore-pressure dissipation (Fig. lb). On the other hand, if drainage is impeded, loading is accompanied by an increase in pore pressure and consolidation will be very small (Fig. lc), because normal stress is supported to a large extent by water in the pores.

Therefore, sediment compaction is governed by effective stress $\sigma_{z}^{\prime}$, defined as

$$
\sigma_{z}^{\prime}=\sigma_{z}-p_{w}
$$

where $p_{\mathrm{w}}$ is pore-water pressure.

From the stress history of sediments over-ridden by glaciers, conclusions regarding the subglacial hydraulic 


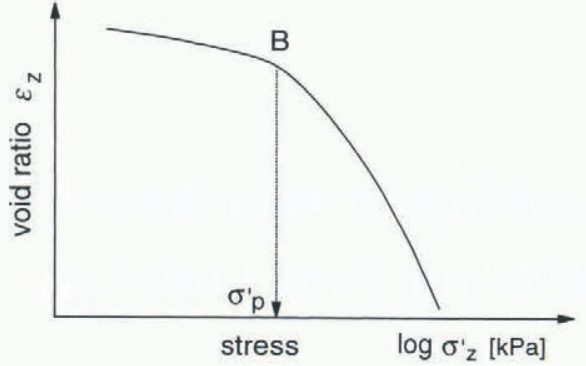

Fig. 2. Typical consolidation curve from an oedometer test.

Point $B$ corresponds to the pre-consolidation stress $\sigma_{\mathrm{p}}^{\prime}$.

regime can be drawn. In overconsolidated sediments the past pre-consolidation stress $\sigma_{\mathrm{p}}^{\prime}$ caused by ice loading is greater than the recent overburden stress $\sigma_{0}^{\prime}$, indicating favourable conditions for pore-water dissipation under the ice sheet. The relation of these two stresses defines the over consolidation ratio (OCR):

$$
\mathrm{OCR}=\frac{\sigma_{\mathrm{p}}^{\prime}}{\sigma_{\mathrm{o}}^{\prime}}
$$

where $\sigma_{\mathrm{o}}^{\prime}$ is derived from the bulk density of the overlying sediments and their thickness.

The pre-consolidation stress is determined in a conventional oedometer consolidation test (Terzaghi, 1923), in which an undisturbed sample is subjected to a uniaxial normal stress that is stepwise increased. Void ratios $\varepsilon_{z}$ reached at the end of each stress increment are plotted against the corresponding normal stress $\sigma_{z}^{\prime}$ (Fig. 2). After reaching a yield point $\mathrm{B}$, the curve dips steeply, indicating the transition between largely elastic and largely permanent deformation. Point B corresponds to the pre-consolidation stress $\sigma_{\mathrm{p}}^{\prime}$, the highest effective stress that has ever been applied to the sediment. The position of point $\mathrm{B}$ can be determined graphically using, for example, the method of Casagrande (1936).

For soft sediments over-ridden by a glacier, $\sigma_{\mathrm{p}}^{\prime}$ depends on the ice-overburden pressure and the palaeo-pore-water pressure. In this study, other factors potentially influencing $\sigma_{\mathrm{p}}^{\prime}$ such as diagenetic consolidation, weathering, ion exchange, fluctuations of $\mathrm{pH}$ and temperature, changes of sed-

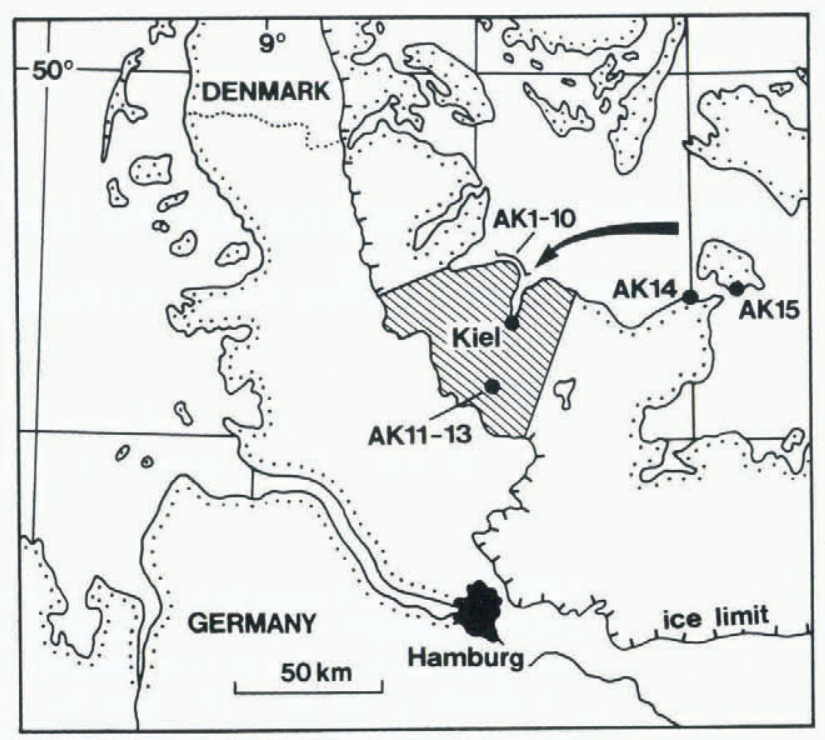

Fig. 3. Study area (hatched) and the sample localities (AK1-AK15). Arrow indicates the main ice-movement direction of the Weichselian glaciation. Weichselian ice limit is shown.

iment structure caused by secondary consolidation and decrease of pore-water pressure caused by lowering of the ground-water table are not taken into account as they are probably of secondary significance given the geographic setting of the samples and their relatively young age (Weichselian glaciation). Furthermore, the net effect of these factors would probably be to increase the consolidation, which would not affect our conclusions qualitatively.

\section{SEDIMENT SAMPLING AND COMPRESSION TESTS}

Weichselian sediments grouped in three regions of northwestern Germany were sampled at different distances from the maximum ice limit (Fig. 3; Table 1). Samples AK1-AK10 come from the lower sedimentary complex of the Baltic Sea cliff north of Kiel (Piotrowski, 1994c). Five samples were taken from sub-aquatic flow tills deposited in a water-filled basin, which developed in front of the Weichselian ice sheet

Table 1. Basic sedimentological data for sampled Weichselian sediments. $C$ is clay, Si is silt, $S$ is sand, $G$ is gravel, $M_{\mathrm{d}}$ is median, $U$ is coefficient of uniformity $\left(D_{60} / D_{10}\right), C_{\mathrm{c}}$ is coefficient of curvature $\left(D_{30}^{2} / D_{60} D_{10}\right)$, w is water content, PL is plastic limit and $L L$ is liquid limit

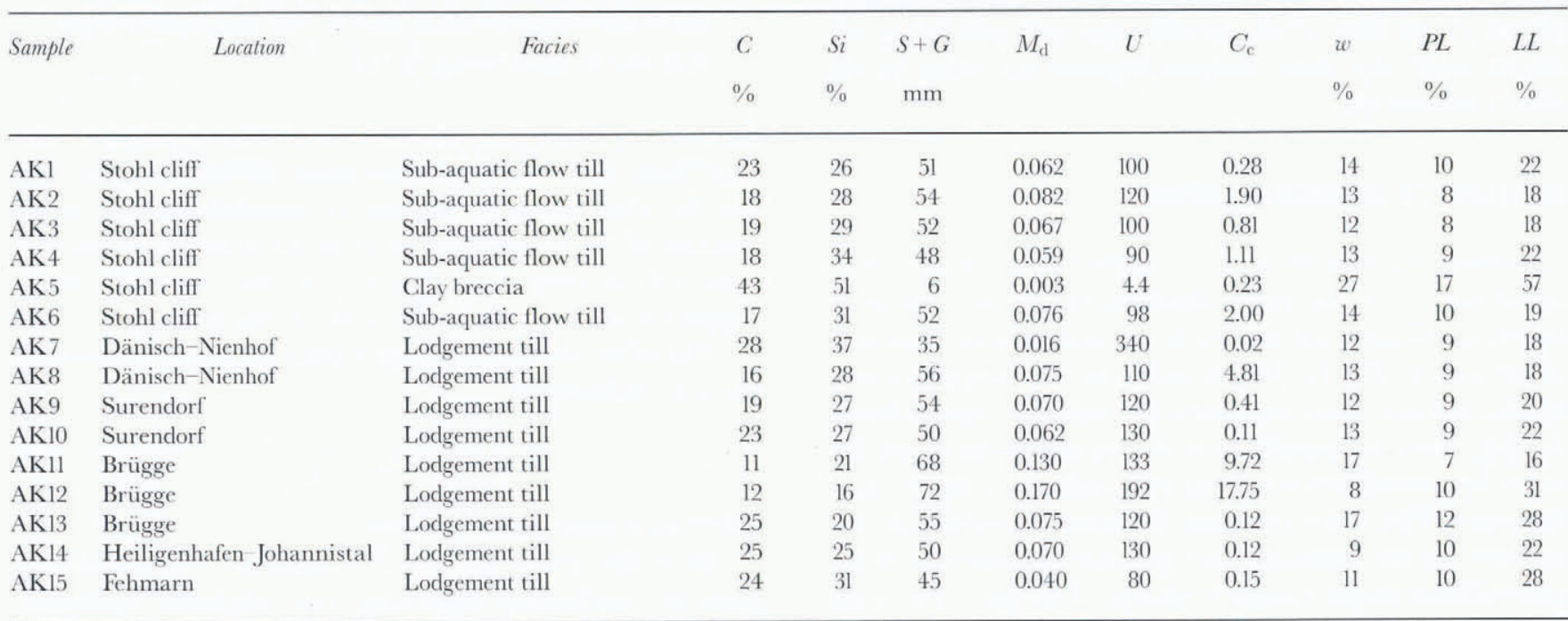


advancing out of the Baltic Sea depression on to the older highlands (Piotrowski, 1994c). An additional sample originates from brecciated glaciolacustrine clay deposited in the same environment. These sediments were subsequently over-ridden by the glacier, which reached its maximum about $40 \mathrm{~km}$ further to the southwest. Another four samples were taken from a lodgement till (sensu Dreimanis, 1989), which was deposited on top of the over-ridden water-laid sediments.

The second group of samples (AK11-AK13) was taken in a gravel quarry at Brügge Bissee, about $13 \mathrm{~km}$ inside the ice limit. They are from lodgement tills deposited on top of largely undisturbed Saalian and Eemian strata (Marks and others, 1995, fig. 3).

Samples AK14 and AK15 originate from lodgement tills in a Baltic Sea cliff about $80-90 \mathrm{~km}$ inside the ice limit at Heiligenhafen-Johannistal and the Isle of Fehmarn, respectively. At both localities, thick Tertiary clays (Tarras-Ton) with very low hydraulic permeability occur just a few metres below the sampled sediments. These clays constitute a regional aquitard at the base of the Quaternary deposits.

At all localities, the undisturbed samples were collected from unweathered sediments at least several metres below the present land surface and at least about $40 \mathrm{~cm}$ into the fresh exposure wall. Only massive units with no evidence of fissures or joints were sampled. Steel cylinders, $10 \mathrm{~cm}$ in diameter and $20 \mathrm{~cm}$ long, were mechanically driven into the sediment and then cut out. In the laboratory, specimens for oedometer testing were prepared by pressing a steel cutting ring into the central part of the cylinder to extract the sediment for mounting in the oedometer cell. The steel rings were $50 \mathrm{~mm}$ in diameter and $14 \mathrm{~mm}$ high. Every sample was tested in at least two parallel experiments. Sedimentological data for the samples are given in Table 1.

In the oedometer experiments under fully drained conditions and with a fixed cutting ring, samples were loaded in ten successively greater stress increments from 19.6 to $6272 \mathrm{kPa}$, to ensure that the pre-consolidation stresses were clearly exceeded. Each load increment was applied for 24 hours. After 24 hours consolidation had essentially stopped. At the end of the test the stress was reduced to that of the first stress increment.

All consolidation curves exhibit initially elastic and then permanent sediment deformation (example in Figure 4). In some samples, determination of the pre-consolidation stress $\sigma_{p}^{\prime}$ was not unequivocal, because of the similar dip angle of both parts of the curve or a rather long transition between the two. Despite several repeated tests, sample AK10 yielded no clear data and will be omitted from further considerations. The pre-consolidation stresses were determined

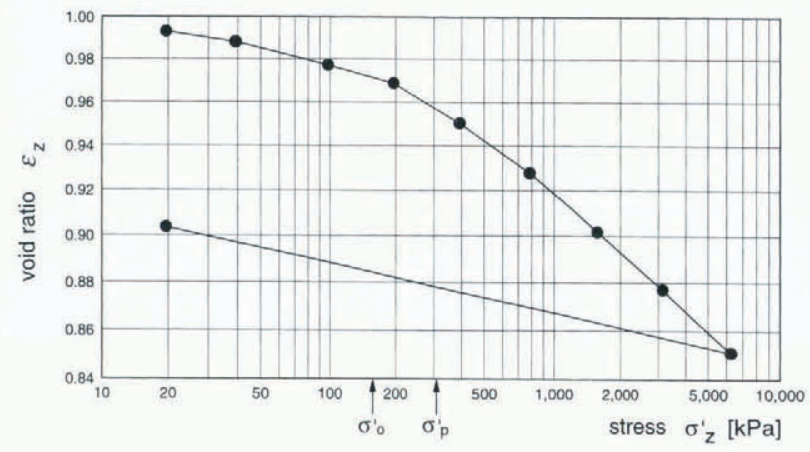

Fig. 4. Consolidation curve for sample AK9/II with pre-consolidation stress $\sigma_{\mathrm{p}}^{\prime}$ and recent overburden stress $\sigma_{\mathrm{o}}^{\prime}$.
Table 2. Averaged stress parameters $\sigma_{\mathrm{o}}^{\prime}$ (recent overburden stress) and $\sigma_{\mathrm{p}}^{\prime}$ (pre-consolidation stress), overconsolidation ratios (OCR) and ice thickness above the potentiometric surface ( $h_{\text {eff }}$ ) calculaled from $10 \mathrm{kPa} \approx 1.11 \mathrm{~m}$ and assuming $95 \%$ consolidation. Although $100 \%$ consolidation requires infinite time, after $95 \%$ consolidation is reached, additional compression is very slow (Taylor, 1948) and can be neglected for practical reasons (Sauer and Christiansen, 1991)

\begin{tabular}{lrrrr}
\hline Sample & $\sigma_{\mathrm{o}}^{\prime}$ & $\sigma_{\mathrm{p}}^{\prime}$ & OCR & $h_{\text {eff }}$ \\
& $\mathrm{kPa}$ & $\mathrm{kPa}$ & & $\mathrm{m}$ \\
& & & & \\
\hline AK1 & 260 & 525 & 2.02 & 61 \\
AK2 & 260 & 310 & 1.19 & 36 \\
AK3 & 330 & 380 & 1.15 & 44 \\
AK4 & 320 & 230 & 0.72 & 27 \\
AK5 & 415 & 540 & 1.30 & 62 \\
AK6 & 370 & 340 & 0.92 & 40 \\
AK7 & 170 & 270 & 1.59 & 32 \\
AK8 & 350 & 350 & 1.00 & 41 \\
AK9 & 160 & 245 & 1.53 & 29 \\
AK11 & 220 & 240 & 1.09 & 28 \\
AK12 & 210 & 230 & 1.10 & 27 \\
AK13 & 40 & 78 & 1.94 & 9 \\
AK14 & 100 & 140 & 1.40 & 16 \\
AK15 & 100 & 140 & 1.40 & 16 \\
& & & & \\
\hline
\end{tabular}

using the graphical method of Casagrande (1936) (see Craig, 1988, p. 238-46). The test results are summarized in Table 2, where data for parallel tests for the same sample have been averaged to give mean values for each sample. Averaging was applied only to parallel samples which yielded similar consolidation curves and $\sigma_{\mathrm{p}}^{\prime}$ values which did not differ by more than $100 \mathrm{kPa}$.

All samples exhibited unexpectedly low $\sigma_{\mathrm{p}}^{\prime}$ values which, in relation to the recent overburden stress $\sigma_{0}$ give very low overconsolidation ratios; in a few cases the recent overburden stress was even roughly equal to the maximum pre-consolidation stress. If pore-water had been at atmospheric pressure upon loading by the glacier, the implied ice thicknesses range between 9 and $61 \mathrm{~m}$. Clearly, these are unrealistically low values and instead must be considered as being representative of the ice thickness above the potentiometric surface (Table 2; see also Sauer and others (1993) for a similar conclusion). Pore-water pressures were apparently very near or at the ice-overburden pressure. This can be explained by generally low hydraulic transmissivity of the substratum which hampered efficient drainage of subglacial meltwater. In the study area, aquitards with conductivities of about $2 \times 10^{-7} \mathrm{~ms} \mathrm{~s}^{-1}$ dominate volumetrically over aquifers by a ratio of 1.6:1 (Piotrowski and others, 1996; Piotrowski, 1997a), so that the drainage capacity of the glacier bed was easily exceeded. Piotrowski (1997a) has shown that only about $25 \%$ of meltwater released subglacially could have been evacuated to the ice-sheet foreground as groundwater flow (see also Piotrowski, 1994b, 1997b).

The relation between high pore-water pressure and the hydraulics of the substratum is particularly obvious for samples AK14 and AK15, which are underlain by thick Tertiary clays. When over-ridden by the glacier, this regional aquitard hindered meltwater drainage from the ice base and triggered pore-water pressure build-up in the sediment to heads corresponding to the flotation point. At those localities, the inferred ice thickness above the potentiometric sur- 
face was about $16 \mathrm{~m}$, while the inferred total ice thickness $h$ was probably about $400 \mathrm{~m}$ (calculated from $h=$ $(A \sqrt{L}+t) \times 1.25(\mathrm{cf}$. British Glaciological Society, 1949) with $A=1.0$ as an approximation for a low-profile ice slope (e.g. Mathews, 1974; Sauer and others, 1993), L (distance to ice margin $)=85000 \mathrm{~m}, t$ (topographic correction, accounting for the difference in elevation between the ice bed at the sampled locality and the ice margin $)=28 \mathrm{~m}$ and corrected for 25\% isostatic depression (Embleton and King, 1975, p. 171)).

There is no clear relationship between the pre-consolidation stresses and distance to the ice margin (i.e. ice thickness), which indicates that sediment consolidation was largely controlled by hydraulic properties of the substratum.

One important conclusion from the above is that the method of inferring past ice thickness from pre-consolidation stresses in over-ridden sediments must be treated with extreme caution (cf. Boulton and Dobbie, 1993). Indeed, ice thickness in Finland calculated by Aario (1971) from preconsolidation data was much smaller than could be accepted, based on independent geological data. Brown and others (1987) calculated ice thicknesses for the Puget Lowland, which turned out to be about three times too small. Also, ice thicknesses obtained by the same method for northern Germany by Khera and Schulz (1984) are about one order of magnitude too small in comparison with other evidence. The same refers to the data of Alai-Omid (1976) reconstructed for parts of northwestern Germany. The reasons most often quoted for these unreliable results were problems with consolidation tests and sample disturbances, sediment weathering and early diagenesis, macroscopically invisible discontinuities and inhomogeneity in the case of glacial tills. If these error sources are minimized, compression tests may yield accurate ice thickness only above the potentiometric surface, which can differ substantially from the total ice thickness. Examples of total ice-thickness calculations from consolidation parameters cross-checked and confirmed by independent data (e.g. Harrison, 1958; Kazi and Knill, 1969) can possibly be explained by exceptionally high hydraulic transmissivities of the substratum.

\section{DID SUBGLACIAL SEDIMENTS DEFORM PERVASIVELY?}

Considering high pore-water pressures, pronounced deformations of the sediment can be expected. The shear strength, $\tau_{\mathrm{f}}$, of sediment is given by the Coulomb equation

$$
\tau_{\mathrm{f}}=c+\left(\sigma_{z}-p_{\mathrm{w}}\right) \tan \phi
$$

where $c$ is cohesion and $\phi$ is angle of internal friction. High pore-water pressures facilitate sediment deformation by reducing the effective normal stress, $\sigma_{z}-p_{\mathrm{w}}$, on the sediment. From the high pore-water pressures inferred above, it follows that deformation of subglacial sediment must be considered a strong possibility for the study area.

Deforming beds have been discovered beneath modern glaciers resting on unconsolidated sediments in Iceland (Boulton, 1979, 1987; Boulton and Jones, 1979), in North America (Engelhardt and others, 1978), in the Alps (Schlüchter, 1983) and are believed to occur beneath some ice streams in Antarctica (Blankenship and others, 1986; MacAyeal, 1989). Boulton and Hindmarsh (1987) believed that sediment deformation beneath Breiðamerkurjökull (Iceland) contributes between 80 and $95 \%$ of the forward movement of the glacier. Beneath Trapridge Glacier

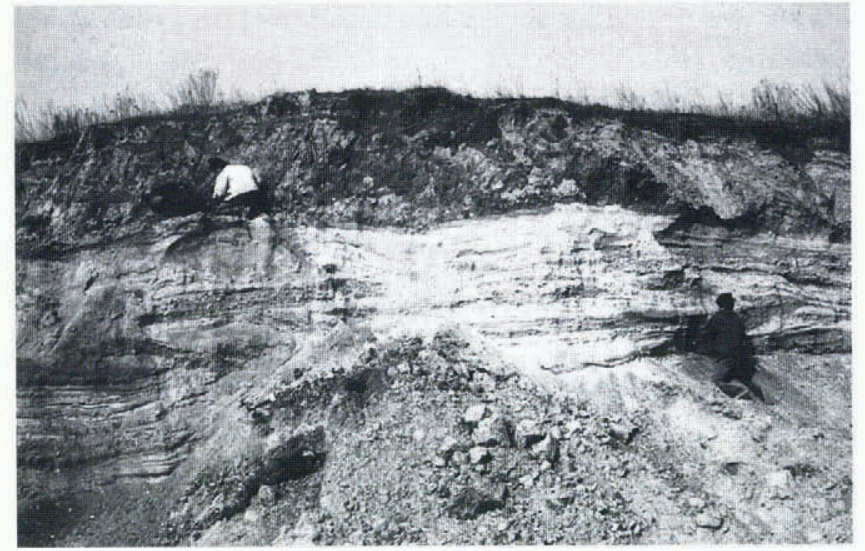

Fig. 5. Undisturbed, bedded outwash sand and gravel under a Weichselian till. Gravel pit at Brügge, about $15 \mathrm{~km}$ south of Kiel.

(Yukon), deformation of the subglacial till accounts for more than half of the motion (Clarke and others, 1984).

Beds that underwent significant deformation are also postulated to have existed beneath large parts of the Pleistocene ice sheets (Menzies, 1989; Hart and others, 1990; Alley, 1991; van der Meer, 1994), although this issue and particularly the sedimentological evidence are still a subject of debate (e.g. Brown and others, 1987; Attig and others, 1989; Clayton and others, 1989). Obviously, the presence or absence of a subglacial deforming layer has serious consequences for glacier dynamics and therefore for the stability of ice sheets.

Analysis of geological data from northwestern Germany has led Piotrowski (1994a, 1995) to the conclusion that the Weichselian ice sheet advanced over a relatively stable substratum with no evidence preserved of pervasive strain of the bed sediments. This refers both to the older strata overridden by the glacier and to the major part of the Weichselian till itself.

Pervasive deformation of the sub-till sediments is considered unlikely, because these sediments are, in most accessible exposures, typically undisturbed (Fig. 5), with the exception of large-scale folds indicative of low strain rates. In most cases, these sediments are stratified sands and gravels separated from the overlying till by a sharp disconformity. There is no gradual transition in to the till, as would

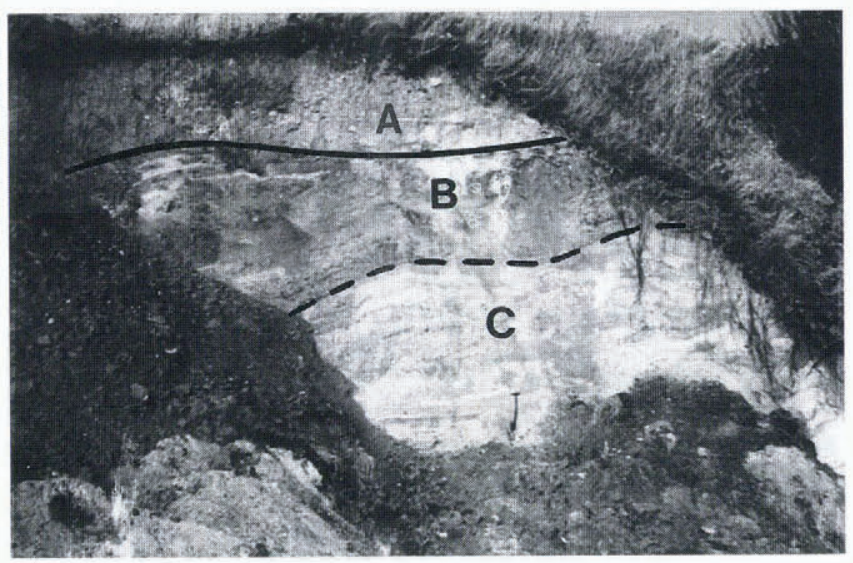

Fig. 6. Undisturbed Eemian palaeosol (B, brown earth) with truncated humus horizon, developed on Saalian outwash (C) and covered by Weichselian till (A). Exposure at Siek, about $20 \mathrm{~km}$ south of Kiel. 


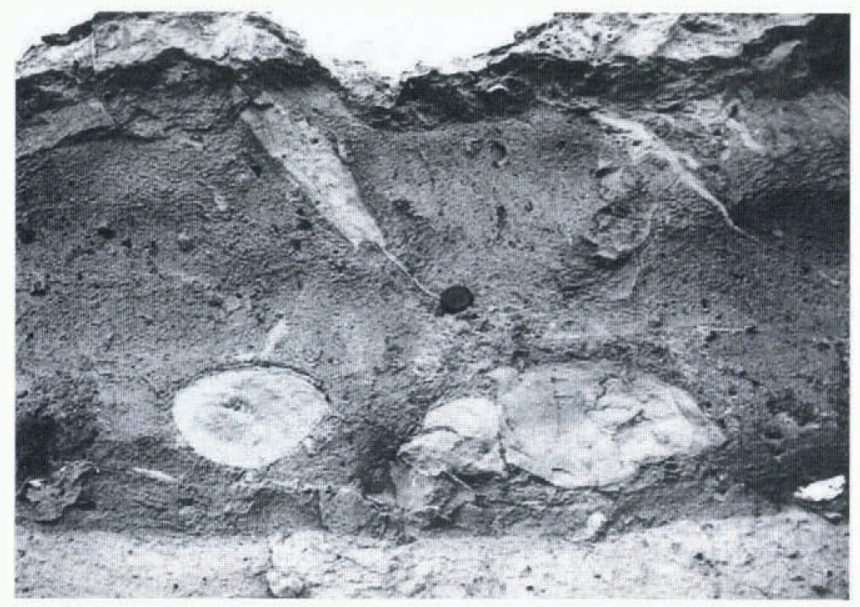

Fig. 7. Sand clusters at the base of Weichselian till indicating low homogenization of till and thus low deformation rates. Saalian till is visible in the lowermost $20 \mathrm{~cm}$. Gravel pit at Brügge, about $15 \mathrm{~km}$ south of Kiel.

be expected if the sub-till sediments had been subjected to pervasive deformation. Because there is little doubt that the bed was in contact with ice before the till had been emplaced, it seems that basal shear stresses have not caused any significant deformation of the bed. This is also indicated by the preservation of Eemian palaeosols beneath Weichselian tills. There are well over 30 documented localities in northwestern Germany, where Eemian weathering horizons underlie the Weichselian till (Stephan, 1981; Felix-Henningsen and Stephan, 1982; Walther, 1990, p.34; Piotrowski, 1996, p. 89). In most cases, these are remarkably well-preserved, largely undisturbed brown earths, para-brown earths and pseudogleys. Typically, only the uppermost centimetres of these palaeosoils are truncated or sheared to some degree but complete profiles are also known. Figure 6 shows a well-preserved Eemian brown earth developed on undisturbed Saalian outwash. Only the humus horizon is truncated and the soil is capped by the Weichselian till.

It may be argued that the subglacial deforming bed was only restricted to the concurrent till, which was separated from the underlying sediments by a rheological boundary. This till is typically up to a few metres thick and, where not covered by outwash, it is the surficial sediment. Although there has undoubtedly been some deformation within the till layer, there is at present no evidence of a widespread pervasive deformation. This is indicated by the following data:

1. If till deformation was significant, the till should now be concentrated near the ice-sheet limit (Haeberli, 1981). This is not the case for the Weichselian till in the study area. Till thickness is somewhat uniform and local thickness undulations do not correlate with the distance to the ice terminus. Although several conspicuous end moraines are present, which indicate considerably long icefront stagnation coupled with efficient sediment supply, there is no evidence of till pile-up due to transport in the deforming bed on proximal sides of these moraines. Outwash concentrations along the former ice margin correlate well with outlets of subglacial meltwater channels (e.g. Ehlers and Wingfield, 1991, fig. 1; Piotrowski, 1994b) and cannot be attributed to ice streams potentially capable of transporting outwash sediments.

2. Although there is no agreed criterion to identify posi-

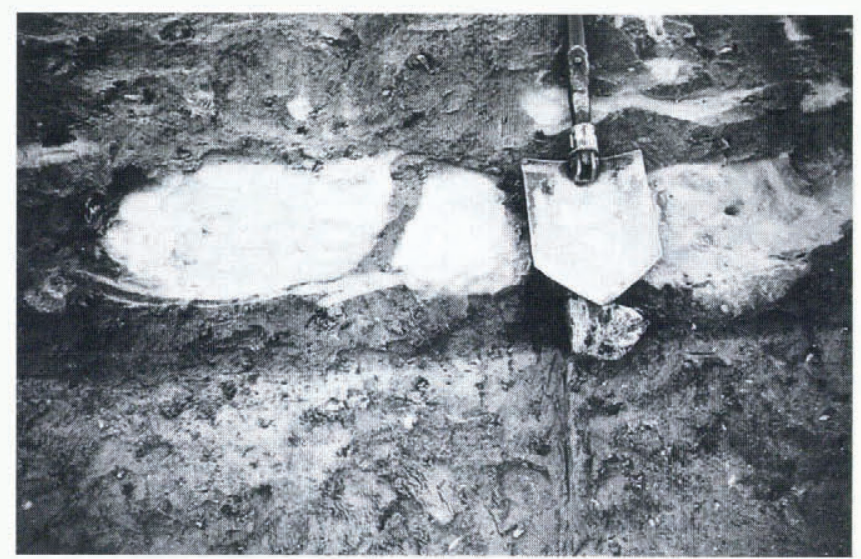

Fig. 8. Slightly deformed sand clusters at the base of Weichselian till indicating low homogenization of till and thus low deformation rates. Massive Saalian till underlies the Weichselian till. Gravel pit at Bissee, about $14 \mathrm{~km}$ south of Kiel.

tively a till that has been pervasively deformed to large strains (Paterson, 1994, p. 170), it seems possible to define structural features that indicate that a till has not been pervasively deformed. Because advanced deformation leads to material homogenization, intact clusters of unconsolidated sorted sediments in till indicate that this till was unlikely to have undergone any pronounced deformation. In numerous sections, the Weichselian subglacial tills indeed contain irregular to sub-rounded inclusions of sand and silt, which are typically up to about $0.5 \mathrm{~m}$ in diameter (Figs 7 and 8). Such clusters occur mostly in the basal parts of the tills. The clusters occasionally exhibit brittle deformations such as fractures and their upper surfaces are often smoothed or truncated. They are interpreted as parts of the substratum that have been incorporated into the glacier base, transported some distance and then redeposited together with the till matrix. Although some minor post-sedimentary movement probably occurred, the largely intact structure of the clusters and the sharp lithological boundary with the till preclude any significant sediment homogenization.

Sediment deformations in the study area seem to be restricted to largely isolated low-strain glaciotectonic phenomena that occur in spatially isolated areas of wedging-

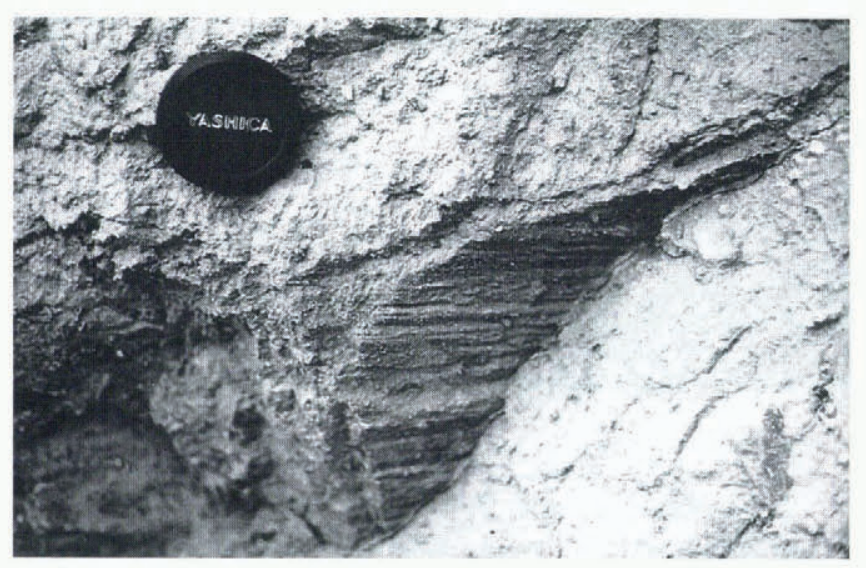

Fig. 9. Ploughing marks within a till at the Baltic Sea cliff at Marienfelde, about $15 \mathrm{~km}$ north of Kiel. 


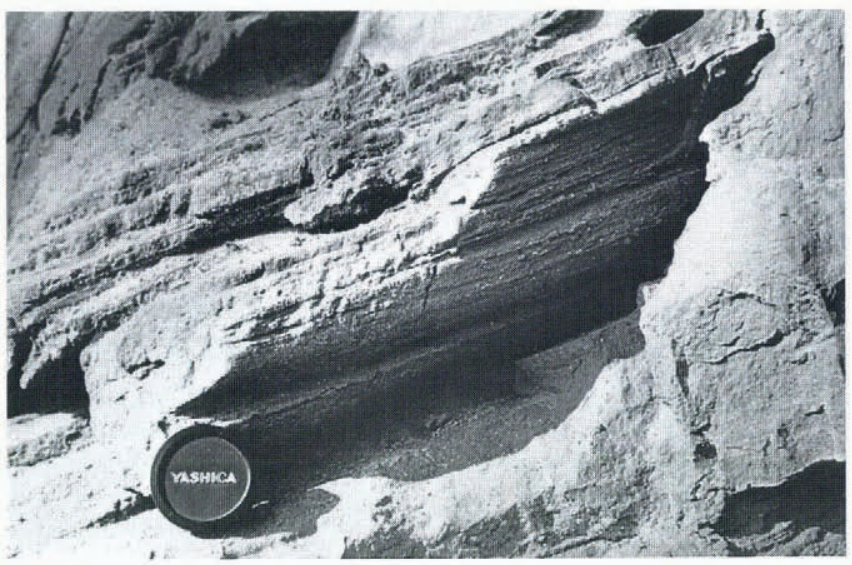

Fig. 10. Heavily ploughed and occasionally fractured till at the Baltic Sea cliff at Friedrichsort, about $5 \mathrm{~km}$ north of Kiel.

out subglacial aquifers, areas of pronounced older topography, areas of sharp lithologic contrasts in the substratum (e.g. fine-grained infills of tunnel valleys) and where the ice sheet advanced over permafrost (Piotrowski, 1993). Deformation in the Heiligenhafen area (sample AK14) is of preWeichselian (Saalian) age and little is known about the palaeo-glaciologic conditions at that time.

\section{ICE MOVEMENT BY BASAL SLIDING}

If subglacial sediment deformation did not contribute much to the ice movement in the study area, the movement must have been focused along the ice bed interface. Indeed, there is good evidence to demonstrate glacier sliding over the bed. In numerous places, ploughing marks and slickensides occur both at the till base and within the till itself (Figs 9 and 10). Occasionally, there are thin silt and clay laminae along these discontinuities which indicate temporal ice-bed separation in addition to ice motion (Fig. 11). Brown and others (1987) also found that either sliding at the ice till interface or localized shearing was probably the main icemotion component under high subglacial water-pressure conditions of the Puget lobe in North America. Ehlers and Stephan (1979) gave examples of features at the base of tills such as ribs, wedges, edges, slickensides and undulations

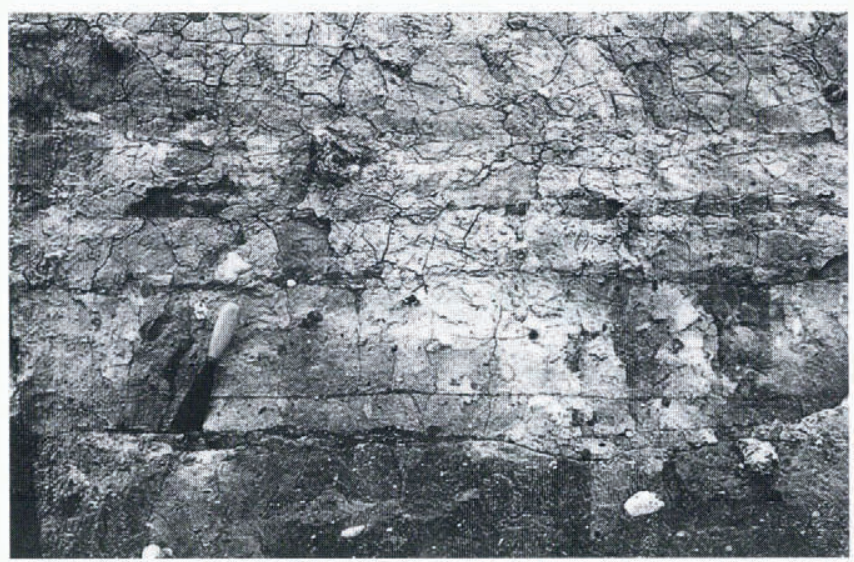

Fig. 11. Sub-horizontal fractures in basal till at the Baltic Sea cliff at Surendorf, about $20 \mathrm{~km}$ northwest of Kiel. Fractures are filled with silty clay (e.g. below the spatula), which indicates ice-bed decoupling. Fractures exhibit minute slickensides in places and they are interpreted as sliding planes at the glacier base.

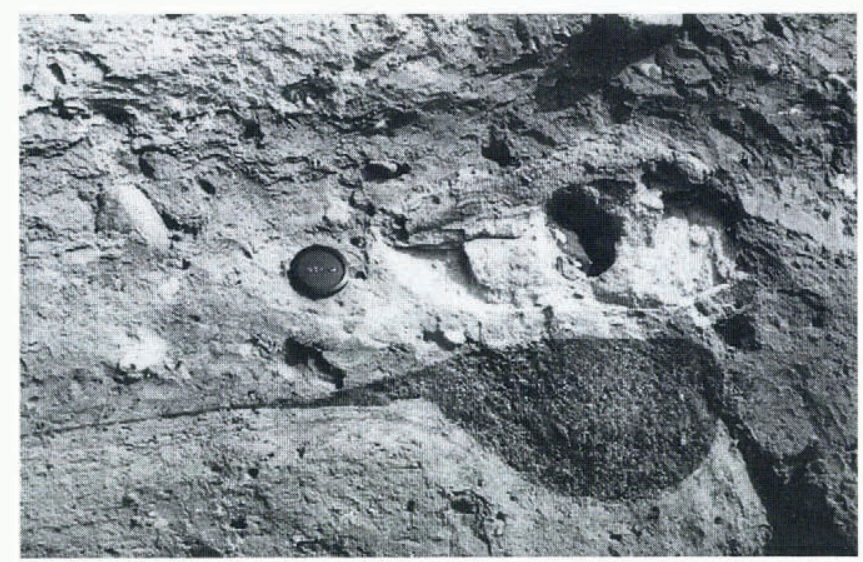

Fig. 12. Heavily weathered crystalline boulder with dispersion tail stretching in the down-ice direction (to the left) from the upper, flattened surface of the boulder. The boulder is resting in the till matrix. The tail originated due to erosion of the upper surface of the boulder by the sliding ice base. The boulder was embedded in largely stable subglacial sediment (see Fig. 14b). Gravel pit at Brügge, about $15 \mathrm{~km}$ south of Kiel.

from northwestern Germany, which also indicate ice sliding over the substratum.

Another group of evidence for sliding is tails on upperlee sides of allochthonous blocks embedded in till (Figs 12 and 13). Figure 12 shows a weathered crystalline boulder abraded on top and stretched down-ice for several decimetres. Note a sand cluster above the boulder which, for the reasons given above, makes pervasive deformation unlikely. Furthermore, if this sediment section was to deform pervasively, the boulder should be expected to have rotated, which should have led also to a second, shorter dispersion tail at the bottom in the opposite direction, as shown schematically in Figure 14a. Instead, the boulder was probably stabilized to a large degree after its emplacement and it was simply subjected to abrasion by the ice sole sliding above (see Fig. 14b). A similar feature is shown in Figure 13, where a lens of sandy till is stretched only downice, at the top.

In a few exposures, bedded sediments underlying till are

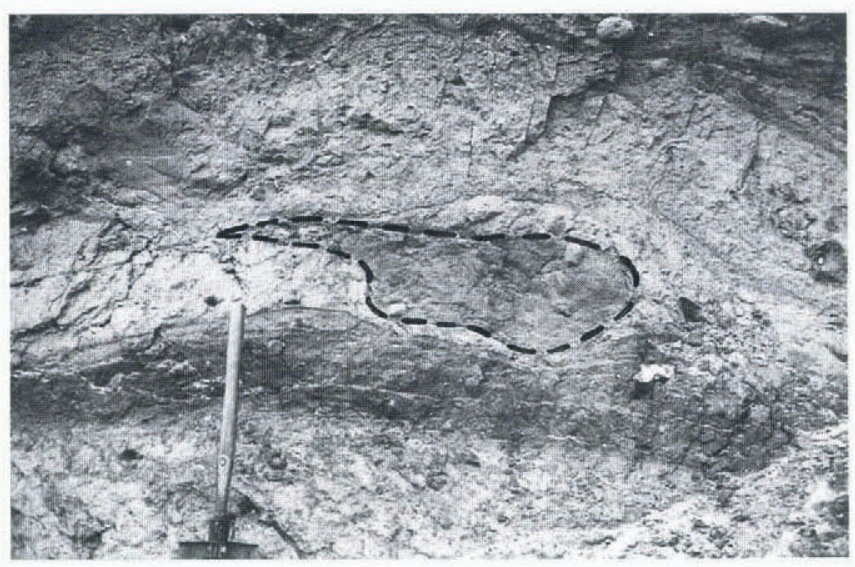

Fig. 13. Cluster of a sandy till with dispersion tail stretching in the down-ice direction (to the left) from the upper corner of the cluster. The cluster is embedded in a silty clay Weichselian till. Explanation as in Figure 12. Gravel pit at Brügge, about $15 \mathrm{~km}$ south of Kiel. 
a



b

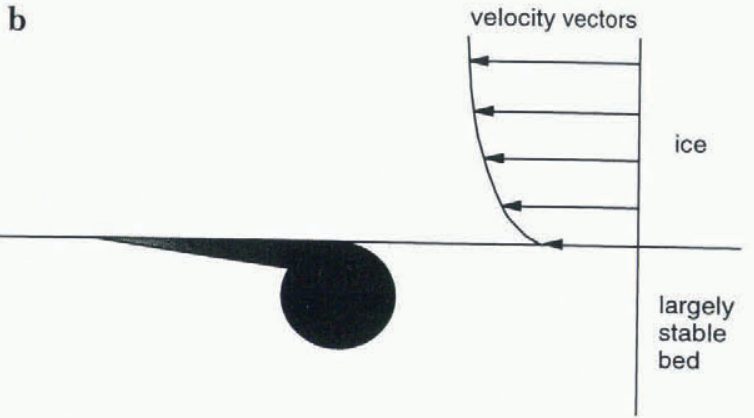

Fig. 14. Simplified model representation of erosion tails from a clast below an active ice base moving over a deforming bed ( a) and moving over a largely stable bed ( $b$ ). In ( $a)$, vertical distribution of velocity vectors in the deforming bed is such that the deformation rate increases towards the ice base. Therefore, clasts tend to be dragged forward over the substratum, which should lead to dispersion trails on the lower up-ice side of the clast. At the same time, a dispersion tail is produced on the upper down-ice side, where sliding velocity exceeds the deformation rate. This process can be accompanied by clast rotation in the case of well-rounded clasts. In (b), the clast rests firmly within the largely stable bed and the dispersion tail originates only in the down-ice direction along the sliding base of the glacier.

sheared along sub-horizontal planes to a depth of about $20-$ $30 \mathrm{~cm}$, named by Stephan (1989) a zone of intensive shear- ing. The spacing between individual planes and the magnitude of displacement decreases downwards. In most cases, the maximum measured slip is not more than a few decimetres, so that the contribution of shearing of sub-till sediments to ice motion was rather limited.

All these data strongly suggest that mainly basal sliding and ploughing were major mechanisms of ice motion which was focused at the glacier sole. Apparently, pore-water pressures near the ice-overburden pressure reduced the strength of the ice-sediment interface much more than that of the sediment. This was recently demonstrated in the modern environment by Iverson and others (1995), who showed that at Storglaciären in northern Sweden shear strain rates of the bed decrease during periods of high water pressures and surface speed. This suggests that fast glacier flow may be associated with some combination of ice sliding over the substratum and ploughing rather than with pervasive bed deformation (Clark, 1995; Iverson and others, 1995).

\section{CONCLUSIONS}

Reconstruction of palaeo-hydraulics of subglacial finegrained sediments over-ridden by the last ice sheet in northwestern Germany reveal high pore-water pressure in the substratum. Pore-water pressure was probably close to the ice-flotation point and local lifting of the ice sheet from the bed by meltwater seems likely, especially in areas of low hydraulic conductivity of the substratum. Ice bed decoupling along a thin water film reduced transmission of shear stresses on to the bed, which could have resulted in a widespread stability of the substratum. This is also indicated by no evidence of pervasive bed deformation. Locally, however, deformation occurs, so that the study area can be envisaged as a mosaic of largely undeformed substratum with isolated spots of deformed bed where probably no significant reduction in ice-to-bed contact occurred (Fig. 15). The outermost part of the ice sheet which rested on permafrost, together with these spots, has supported glacial stresses and stabilized the ice sheet. The major contribution to ice movement was probably basal sliding and ploughing on top of the overpressured substratum sediments.

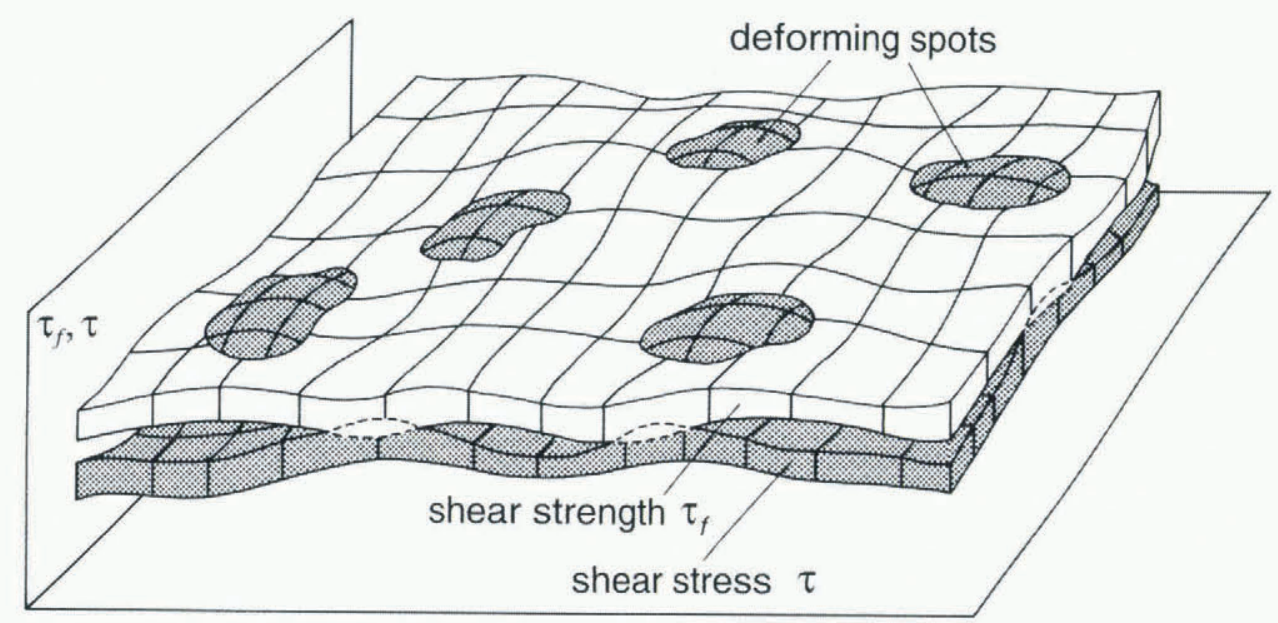

Fig. 15. Schematic representation of the relationship between subglacial shear stresses $\tau$ and shear strength of subglacial sediments $\tau_{\mathrm{f}}$ for the study area. The shear stresses transmitted to the ice bed were typically lower than the sediment shear strength, which was caused by reduced ice- bed coupling as a result of high basal water pressures. This was the reason for the apparent stability of the glacier substratum. Only where (due to lower water pressure) the shear stress was assumed by the substratum, sediment deformation has occurred. This model implies low deformation rates under conditions of very high water pressures and high ice-movement velocities caused by enhanced basal sliding. 


\section{ACKNOWLEDGEMENTS}

We thank V. Feeser for stimulating discussions. Comments of N. R. Iverson and D. L. Pair on an earlier version of this paper are greatly appreciated. Assistance of K. Blaut, S. Böhler and S. -O. Bude in the field and during compression tests is gratefully acknowledged.

\section{REFERENCES}

Aario, R. 1971. Consolidation of Finnish sediments by loading ice sheets. Bull. Geol. Soc. Finl. 43, 55-65.

Alai-Omid, M. H. 1976. Bodenphysikalische Eigenschaften der glazialen Beckensedimente Schleswig-Holsteins. (Ph.D. thesis, University of Kiel.)

Alley, R. B. 1991. Deforming-bed origin for southern Laurentide till sheets? 7. Glaciol., 37 (125), 67-76.

Attig, J.W., D. M. Mickelson and L. Clayton. 1989. Late Wisconsin landform distribution and glacier-bed conditions in Wisconsin. Sediment. Geol., 62(3-4), 399-405.

Blankenship, D. D., C. R. Bentley, S. T. Rooney and R. B. Alley. 1986. Seismic measurements reveal a saturated porous layer beneath an active Antarctic ice stream. Nature, 322 (6074), 5457.

Boulton, G. S. 1979. Processes of glacier erosion on different substrata. $\mathcal{f}$. Glaciol., 23 (89), 15-38.

Boulton, G. S. 1987. A theory of drumlin formation by subglacial sediment deformation. In Menzies, J. and J. Rose, eds. Drumlin Symposium. Rotterdam, A.A. Balkema, 25-80,

Boulton, G. S. and K. E. Dobbie. 1993. Consolidation of sediments by glaciers: relations between sediment geotechnics, soft-bed glacier dynamics and subglacial ground-water flow. F. Glaciol., 39 (131), 26-44.

Boulton, G. S. and R.C.A. Hindmarsh. 1987. Sediment deformation beneath glaciers: rheology and geological consequences. f. Geophys. Res., 92 (B9), 9059- 9082.

Boulton, G. S. and A. S. Jones. 1979. Stability of temperate ice caps and ice sheets resting on beds of deformable sediment. F. Glaciol., 24 (90), 29-43.

Boulton, G. and R. Vivian. 1973. Underneath the glaciers. Geogr. Mag., 45 (4), $311-316$.

British Glaciological Society. 1949. Joint meeting of the British Glaciological Society, the British Rheologists' Club and the Institute of Metals. f. Glaciol., 1 (5), 231-240.

Brown, N. E., B. Hallet and D. B. Booth. 1987. Rapid soft bed sliding of the Puget glacial lobe. 7. Geophys. Res., 92 (B9), 8985- 8997.

Casagrande, A. 1936. The determination of the preconsolidation load and its practical significance. In First International Conference on Soil Mechanics and Foundation Engineering, Proceedings. Vol. 3 Cambridge, MA, 60-64.

Clark, P. U. 1995. Fast glacier flow over soft beds. Science, 267 (5194), 43-44.

Clarke, G. K. C., S. G. Collins and D. E. Thompson. 1984. Flow, thermal structure, and subglacial conditions of a surge-type glacier. Can. J. Earth Sci, 21 (2), 232-240.

Clayton, L., D. M. Mickelson and J. W. Attig. 1989. Evidence against pervasively deformed bed material beneath rapidly moving lobes of the southern Laurentide ice sheet. Sediment. Geol., 62(3-4), 203-208.

Craig, R. F. 1988. Soil mechanics. London, Van Nostrand Reinhold (International).

Dreimanis, A. 1989. Tills: their genetic terminology and classification. In Goldthwait, R. P. and C. L. Matsch, eds. Genetic classification of glacigenic deposits. Rotterdam, A. A. Balkema, 17-83.

Ehlers, J. and H. -J. Stephan. 1979. Forms at the base of till strata as indicators of ice movement. .7. Glaciol., 22 (87), 345-355.

Ehlers, J. and R. Wingfield. 1991. The extension of the Late Weichselian/ Late Devensian ice sheets in the North Sea basin. 7. Quat. Sci., 6(4), 313-326.

Embleton, C. and C. A. M. King. 1975. Glacial geomorphology. Second edition. London, Edward Arnold.

Engelhardt, H. F., W. D. Harrison and B. Kamb. 1978. Basal sliding and conditions at the glacier bed as revealed by bore-hole photography. $\mathcal{F}$. Glaciol., 20 (84), 469-508.

Felix-Henningsen, P. and H. -J. Stephan. 1982. Stratigraphie und Genese fossiler Böden im Jungmoränengebiet südlich von Kiel. Eiszeitalter Ggw., 32, 163-175.

Haeberli, W. 1981. Correspondence. Ice motion on deformable sediments. $\mathcal{F}$. Glaciol., 27 (96), 365-366.

Harrison, W. 1958. Marginal zones of vanished glaciers reconstructed from the preconsolidation-pressure values of overridden silts. F. Geol., 66(1), $72-95$.
Hart, J. K., R. C. A. Hindmarsh and G. S. Boulton. 1990. Styles of subglacial glaciotectonic deformation within the context of the Anglian ice-sheet. Earth Surface Processes and Landforms, 15 3), 227-241.

Iverson, N. R., B. Hanson, R. LeB. Hooke and P. Jansson. 1995. Flow mechanism of glaciers on soft beds. Science, 267 (5194), 80-81.

Kazi, A. and J. L. Knill. 1969. The sedimentation and geotechnical properties of the Cromer till between Happensburgh and Cromer, Norfolk. Q. f. Eng. Geol., 2, $63-80$.

Khera, R. P. and H. Schulz. 1984. Past consolidation stress estimates in Cretaceous clay. ASCE 7. Geotech. Eng., 110, 189 202.

MacAyeal, D. R. 1989. Large-scale ice flow over a viscous basal sediment: theory and application to Ice Stream B, Antarctica. 7. Geophys. Res. 94 (B4), 4071-4087.

Marks, L., J. A. Piotrowski, H. -J. Stephan, S. Fedorowicz and J. Butrym. 1995. First thermoluminescence indications of the Middle Weichselian (Vistulian) glaciation in northwest Germany. Meyniana, 47,69 82.

Mathews, W. H. 1974. Surface profiles of the Laurentide ice sheet in its marginal areas. f. Glaciol., 13 (67), 37-43.

Menzies, J. 1989. Subglacial hydraulic conditions and their possible impact upon subglacial bed formation. Sediment. Geol., 62 (3-4), 125-150.

Paterson, W. S. B. 1994. The physics of glaciers. Third edition. Oxford, etc., Elsevier.

Piotrowski, J. A. 1993. Salt diapirs, pore-water traps and permafrost as key controls for glaciotectonism in the Kiel area, northwestern Germany. In Aber, J.S., ed. Glaciotectonics and mapping glacial deposits. Regina, Sask., University of Regina. Canadian Plains Research Center, 86-98, $214-215$.

Piotrowski, J. A. 1994a. Ice flow dynamics and subglacial bed conditions during the Weichselian glaciation in Schleswig Holstein, northwest Germany. Acta Univ. Nicolai Copernici, Geogr., 27 (92), 141-160.

Piotrowski, J. A. 1994b. Tunnel-valley formation in northwest Germany geology, mechanisms of formation and subglacial bed conditions for the Bornhöved tunnel valley. Sediment. Geol., 89 (1-2), 107-141.

Piotrowski, J. A. 1994c. Waterlain and lodgement till facies of the lower sedimentary complex from the Dänischer-Wohld-Cliff, Schleswig Holstein, north Germany. In Warren, W. P. and D. G. Croot, eds. Formation and deformation of glacial deposits. Rotterdam, etc., A. A. Balkema, 3-8.

Piotrowski, J. A. 1995. Glaciodynamic model for northwest Germany: stable/ deforming ice bed mosaic. International Union for Quaternary Research. XVI International Congress, 3-10 August 1995, Berlin, Germany. Abstracts. Bonn, Alfred-Wegener-Stiftung, 219.

Piotrowski, J. A. 1996. Dynamik und subglaziale Paläohydrologie der weichselzeilliche Eiskappe in Zentral-Schleswig-Holstein. Kiel, Universität Kiel. Geologisch und Paläeontologisches Institut. (Report 78.)

Piotrowski, J. A. 1997a. Subglacial groundwater flow during the last glaciation in north-western Germany. Sediment. Geol., 111 (1-4), 217-224

Piotrowski, J. A. 1997b. Subglacial hydrology in north-western Germany during the last glaciation: groundwater flow, tunnel valleys and hydrological cycles. Quat. Sci. Rev., 16(2), 169-185

Piotrowski, J. A., F. Bartels, A. Salski and G. Schmidt. 1996. Geostatistical regionalization of glacial aquitard thickness in northwestern Germany, based on fuzzy kriging. Math. Geol., 28(4), 437-452.

Sauer, E. K. and E. A. Christiansen. 1991. Preconsolidation pressures in the Battleford Formation, southern Saskatchewan, Canada. Can. J. Earth Sci, $28(10), 1613-1623$.

Sauer, E. K., A. K. Egeland and E. A. Christiansen. 1993. Preconsolidation of tills and intertill clays by glacial loading in southern Saskatchewan, Canada. Can. 7. Earth Sci., 30 (3), 420-433.

Schlüchter, C. 1983. The readvance of the Findelengletscher and its sedimentological implications. In Evenson, E. B., C. Schlüchter and J. Rabassa, eds. Tills and related deposits: genesis/petrology/application/stratigraphy. Rotterdam, A. A. Balkema, 95-104.

Stephan, H. -J. 1981. Eemzeitliche Verwitterungshorizonte im Jungmoränengebiet Schleswig Holsteins. Verh. Naturwiss. Ver. Hambg., N.F., 24(2), $161-175$.

Stephan, H. -J. 1989. Origin of a till-like diamicton by shearing. In Goldthwait, R. P. and C. L. Matsch, eds. Genetic classification of glacigenic deposits. Rotterdam, A. A. Balkema, 93-96.

Taylor, D.W. 1948. Fundamentals of soil mechanics. New York, etc., Wiley and Sons.

Terzaghi, K. 1923. Die Berechnung der Durchlässigkeitsziffer des Tones aus dem Verlauf der hydrodynamischen Spannungserscheinungen. Akad. Wiss. Wien, Math.-Naturwiss. Kl., Sitzungsber., Ser. Abt. IIa, 132(3 4), 125138.

Van der Meer, J.J. M. 1993. Microscopic evidence of subglacial deformation. Quat. Sci. Rev., 12 (7), 553-587.

Walther, M. 1990. Untersuchungsergebnisse zur jungpleistozänen Landschaftsentwicklung Schwansens (Schleswig-Holstein). Berl. Geogr. Abh. 52. 